\title{
Hubungan Asupan Energi, Stres Kerja, Aktifitas Fisik, dan Durasi Waktu Tidur dengan IMT pada Manajer Madya Dinas Pemerintah Kota Surabaya
}

\section{Correlation between Energy Intake, Job Stress, Phyisical Activity, and Sleep Duration with BMI in Middle Manager at Surabaya's Government Agency}

\author{
Annisa Risqi Wulandari*, Dhenok Widari ${ }^{1}$,Lailatul Muniroh ${ }^{2}$
}

\begin{abstract}
ABSTRAK
Latar Belakang: Prevalensi status gizi lebih pada penduduk dewasa semakin meningkat di Indonesia. Manajer madya merupakan kelompok yang berisiko mengalami kegemukan karena jenis pekerjaan kantor yang ringan serta rentan mengalami stres kerja. Dukungan ekonomi juga menjadi salah satu faktor pendukung besarnya asupan energi dibandingkan energi yang dikeluarkan untuk beraktifitas. Masalah gizi lebih pada penduduk dewasa dapat memengaruhi status kesehatan dan produktifitas kerja seseorang.

Tujuan: Tujuan penelitian ini adalah untuk menganalisis hubungan antara asupan energi, stres kerja, aktifitas fisik dan durasi waktu tidur dengan Indeks Massa Tubuh (IMT) pada Manajer Madya.

Metode: Penelitian ini adalah observasional dengan desain penelitian potong lintang. Sebanyak 49 manajer madya di Dinas Pemerintah Kota Surabaya dipilih menggunakan metode cluster sampling. Pengumpulan data menggunakan pengukuran antropometri untuk IMT, SQ-FFQ untuk asupan energi, kuesioner OSI-R untuk stres kerja serta recall aktifitas fisik untuk data aktifitas fisik dan durasi waktu tidur. Analisis data menggunakan uji korelasi pearson product moment.

Hasil: Penelitian menunjukkan bahwa sebagian besar responden memiliki status gizi normal (61,2\%), kecukupan energi tergolong baik (47\%), stres kerja tingkat sedang $(69,4 \%)$, aktifitas fisik ringan $(46,9 \%)$ dan sedang $(46,9 \%)$ serta durasi tidur yang kurang $(59,2 \%)$. Terdapat hubungan antara asupan energi $(p=0,001)$ dan durasi waktu tidur $(0,006)$ dengan IMT. Stres kerja $(p=0,227)$ dan aktifitas fisik $(p=0,148)$ tidak berhubungan dengan IMT.

Kesimpulan: Semakin tinggi asupan energi dan semakin singkat durasi waktu tidur maka akan semakin tinggi IMT pada manajer madya.
\end{abstract}

Kata kunci: asupan energi, stres kerja, aktifitas fisik, durasi waktu tidur, IMT, manajer madya

\section{ABSTRACT}

Background: Prevalence of overweight and obesity in adult has increased each year in Indonesia. Middle managers were groups at risk for overweight because their job characteristics such as low physical activity and risk of experiencing job stress. Economy support in middle manager was one of supporting factor which affect to higher amount of energy intake. Overweight in adult can affect on their health status and work productivity

Objectives: The purpose of this study was to analyze the correlation between energy intake, job stress, physical activity and sleep duration with $B M I$ in middle manager.

Methods: This was an observational study with cross sectional design. 49 Middle Manager in Surabaya's Government Agency were selected using cluster sampling. Nutritional status data were collected using anthropometric measurement, energy intake using SQ-FFQ, job stress using OSI-R questionnaire, physical activity and sleep duration data using activity recall. Data were analyzed by Pearson product moment test.

Results: This study showed that most of respondents has normal nutritional status (61.2\%), adequate energy intake (47\%), moderate level job stress (69.4\%), low (46.9\%) and moderate (46.9\%) physical activity level, and lack of sleep duration (59.2\%). There were correlation between energy intake $(p=0.001)$ and sleep duration $(p=0.006)$ with BMI. Job stress $(p=0.227)$ and phyisical activity $(p=0.148)$ had no correlation with BMI.

Conclusions: higher energy intake and lower sleep duration would increase BMI.

Keywords: energy intake, job stress, physical activity, sleep duration, BMI, middle manager 


\author{
*Koresponden: \\ arisqiwulandari@gmail.com \\ ${ }^{1}$ Dinas Kesehatan Kota Surabaya \\ Jl. Raya Jemursari No.197, Sidosermo, Wonocolo, 60239, Surabaya, Jawa Timur, Indonesia \\ ${ }^{2}$ Prodi S-1 Gizi, Fakultas Kesehatan Masyarakat, Universitas Airlangga \\ Kampus C Mulyorejo 66115, Surabaya, Jawa Timur, Indonesia
}

\section{PENDAHULUAN}

Status gizi kurang dan status gizi lebih merupakan masalah gizi yang perlu diperhatikan pada kelompok usia dewasa. Status gizi kurang maupun status gizi lebih pada kelompok dewasa dapat memicu timbulnya penyakit-penyakit tertentu serta memengaruhi produktifitas kerja seseorang. Masalah status gizi pada penduduk dewasa ( $>18$ tahun) di Indonesia saat ini didominasi oleh masalah gizi lebih yang terdiri dari overweight dan obesitas ${ }^{1}$. Overweight dan obesitas terjadi akibat keseimbangan energi positif, yaitu energi yang masuk lebih besar daripada energi yang keluar dalam jangka waktu yang lama ${ }^{2}$.

Berdasarkan laporan Riset Kesehatan Dasar (Riskesdas) tahun 2018, prevalensi kegemukan mengalami peningkatan sejak tahun 2007 hingga saat ini. Pada tahun 2007 prevalensi overweight (IMT $\geq 25,0$ $\mathrm{s} / \mathrm{d}<27 \mathrm{~kg} / \mathrm{m}^{2}$ ) pada kelompok usia dewasa sebesar $8,6 \%$. Angka tersebut meningkat pada tahun 2013 dan 2018 menjadi 11,5\% dan 13,6\%. Prevalensi obesitas (IMT $\geq 27 \mathrm{~kg} / \mathrm{m}^{2}$ ) pada kelompok dewasa di Indonesia juga mengalami peningkatan dari tahun 2007 (10,5\%), 2013 $(14,8 \%)$ dan $2018(21,8 \%)^{3}$.

Data sebaran masalah kegemukan di Indonesia menunjukkan bahwa kegemukan lebih banyak ditemukan pada penduduk yang tinggal di daerah perkotaan daripada penduduk yang tinggal di daerah pedesaan. Selain itu, kondisi kegemukan di Indonesia lebih banyak terjadi pada kelompok yang memiliki pendidikan tinggi dan bekerja sebagai PNS/Pegawai/TNI/Polri ${ }^{4}$.

Manajer madya di dinas-dinas pemerintah merupakan PNS yang memiliki jabatan struktural dalam organisasi pemerintah daerah (OPD) tempat mereka bekerja. Manajer madya memiliki kedudukan dalam sebuah organisasi yang menunjukkan tugas, tanggung jawab, wewenang, dan hak seorang PNS dalam rangka memimpin suatu bagian dari satuan organisasi negara ${ }^{5}$.

Berdasarkan karakteristik pekerjaanya, manajer madya merupakan pekerja kantor. Umumnya, pekerja kantor menghabiskan sebagian besar jam kerjanya di dalam ruangan, sehingga tingkat aktifitas fisik yang dilakukan cenderung ringan ${ }^{6}$. Tingkat perekonomian menengah ke atas pada manajer madya akan meningkatkan kemampuan akses makanan secara ekonomi, sehingga dapat memenuhi kebutuhan makanan secara kualitas dan kuantitas. Hal ini didukung oleh penelitian terdahulu yang menyatakan bahwa ratarata asupan energi PNS di Kanwil Dirjen Perbendaharaan Provinsi Sumatera Utara mayoritas $>100 \%$ AKG $(80 \%)^{7}$.

Dalam menjalankan tugasnya untuk mengelola fungsi manajemen, posisi seorang manajer madya dalam struktur organisasi memiliki perananan ganda ${ }^{8}$, yakni berperan sebagai bawahan, rekan kerja, atasan dan wakil dari perusahaan sehingga memiliki pola hubungan yang lebih rumit rentan mengalami benturan dan pertentangan yang dapat menyebabkan stres dalam dirinya ${ }^{9}$. Di sisi lain, terdapat kemungkinan seorang manajer madya memiliki waktu tidur yang kurang karena kesibukan dan kewajibannya untuk menyelesaikan pekerjaannya.

Penelitian ini bertujuan untuk menganalisis hubungan antara asupan energi, stres kerja, aktifitas fisik dan durasi waktu tidur dengan indeks massa tubuh (IMT) pada manajer madya di Dinas Pemerintah Kota Surabaya.

\section{METODE}

Penelitian ini merupakan penelitian observasional dengan desain penelitian potong lintang. Penelitian ini dilakukan pada bulan Maret hingga September 2018 di beberapa kantor Dinas Pemerintah Kota Surabaya. Populasi penelitian adalah seluruh manajer madya sebanyak 98 orang yang tersebar di seluruh Dinas di Kota Surabaya. Pemilihan sampel menggunakan metode cluster sampling, dengan perhitungan jumlah responden sebanyak 49 orang manajer madya yang tersebar di Dinas Pemerintah Kota Surabaya.

Pengambilan data karakteristik responden dilakukan dengan wawancara meliputi jenis kelamin, pendidikan terakhir dan usia. Pengukuran berat badan dan tinggi badan dilakukan untuk perhitungan IMT. Berat badan diukur menggunakan timbangan digital merk GEA tipe EB 9350 dengan ketelitian 0,1 kg dan tinggi badan diukur menggunakan microtoise $200 \mathrm{~cm}$ dengan ketelitian 0,1 cm. Pengukuran asupan energi dilakukan menggunakan kuesioner Semi Quantitative-Food Frequency Questionnaire (SQ-FFQ). Data asupan energi selanjutnya dianalisis menggunakan program Nutrisurvey 2007 untuk mengetahui tingkat kecukupan energi.

Pengukuran variabel stres kerja menggunakan instrumen kuesioner stres kerja Occupational Stress Inventory-Revised Edition (OSI-R) oleh Osipow dan Spokane yang telah diuji validitas dan reabilitas pada penelitian terdahulu dengan skor total item minimum $r=0$,2. Jumlah pertanyaan yang diajukan terdiri dari 25 pertanyaan dengan pilihan skor 1-5 untuk setiap item pertanyaan. Setelah dilakukan skoring, skor stres kerja dikategorikan menjadi tingkat stres rendah (skor 25-58), sedang (skor 59-92), dan tinggi (93-125) ${ }^{10}$.

Pengukuran aktifitas fisik dilakukan melalui recall aktifitas fisik selama dua kali, yaitu pada saat hari masuk kerja dan pada saat hari libur. Hasil dari wawancara recall aktifitas fisik tersebut kemudian diolah dengan 
cara mengalikan PAR (Phyisical Activity Ratio) dengan lamanya waktu yang digunakan untuk beraktifitas. Besarnya aktifitas fisik yang dilakukan dalam waktu 24 jam dinyatakan dalam PAL (Physical Activity Level). Nilai PAL tersebut kemudian di rata-rata untuk selanjutnya dikelompokkan menjadi 3 kategori yaitu aktifitas ringan $(1,40-1,69)$, sedang $(1,70-1,99)$, dan berat $(2,00-2,40)^{11}$.

Setelah seluruh data terkumpul, dilakukan pengolahan dan analisis data. Analisis yang dilakukan berupa analisis deskriptif yang disajikan dalam tabel distribusi frekuensi. Analisis bivariat menggunakan uji korelasi pearson karena seluruh skala data berdistribusi normal. Penelitian ini telah lolos uji etik dari Komisi Etik Penelitian Kesehatan Fakultas Keperawatan Universitas Airlangga dengan sertifikat nomor 1030-KEPK.

\section{HASIL DAN PEMBAHASAN}

Tabel 1 menunjukkan bahwa lebih dari separuh responden dalam penelitian ini adalah laki-laki $(53,1 \%)$. Hampir seluruh responden memiliki riwayat pendidikan terakhir pada jenjang magister atau S2 (98\%). Usia responden dikelompokkan menjadi 3 , yaitu dewasa awal (18-40 tahun), dewasa madya (41-60 tahun) dan dewasa akhir (>60 tahun). Hasil penelitian menunjukkan bahwa hampir seluruh responden berada pada rentang usia 4160 tahun yang termasuk usia dewasa madya (98\%). Pada usia dewasa madya, seseorang cenderung mengalami perubahan fisiologis seperti penurunan laju metabolisme, penurunan massa otot tubuh dan cenderung kurang aktif bergerak dibandingkan dengan kelompok usia dewasa awal ${ }^{12}$.

Tabel 1. Distribusi Responden Berdasarkan Jenis Kelamin, Pendidikan Terakhir dan Usia Manajer Madya.

\begin{tabular}{lcc}
\multicolumn{1}{c}{ Variabel } & N & (\%) \\
\hline $\begin{array}{l}\text { Jenis Kelamin } \\
\text { Laki-Laki }\end{array}$ & 26 & 53,1 \\
$\quad$ Perempuan & 23 & 46,9 \\
\hline $\begin{array}{l}\text { Pendidikan Terakhir } \\
\quad \text { Diploma }\end{array}$ & 0 & 0 \\
$\quad$ Sarjana & 1 & 2 \\
Magister & 48 & 98 \\
$\quad$ Doktor & 0 & 0 \\
\hline Usia & & \\
$\quad$ Dewasa Awal (18-40 tahun) & 1 & 2 \\
$\quad$ Dewasa Madya (41-60 tahun) & 48 & 98 \\
$\quad$ Dewasa Akhir (>60 tahun) & & \\
& 0 & 0
\end{tabular}

Tabel 2. Status Gizi Manajer Madya Dinas Pemerintah Kota Surabaya tahun 2018

\begin{tabular}{lcc}
\hline \multicolumn{1}{c}{ Status Gizi } & N & (\%) \\
\hline Kurus (IMT $<18,5 \mathrm{~kg} / \mathrm{m}^{2}$ ) & 0 & 0 \\
Normal $\left(\mathrm{IMT} 18,5-24,9 \mathrm{~kg} / \mathrm{m}^{2}\right)$ & 30 & 61,2 \\
Overweight $\left(\mathrm{IMT} 25-26,9 \mathrm{~kg} / \mathrm{m}^{2}\right)$ & 8 & 16,3 \\
Obesitas $\left(\mathrm{IMT} \geq 27 \mathrm{~kg} / \mathrm{m}^{2}\right)$ & 11 & 22,4 \\
\hline
\end{tabular}

Status gizi responden dikelompokkan menjadi 4 kelompok berdasarkan ambang batas IMT untuk orang Indonesia, meliputi kurus (IMT $<18,5 \mathrm{~kg} / \mathrm{m}^{2}$ ), normal (IMT 18,5-24,9 kg/m²), overweight (IMT $25-26,9 \mathrm{~kg} / \mathrm{m}^{2}$ ) dan obesitas (IMT $\geq 27 \mathrm{~kg} / \mathrm{m}^{2}$ ).

Berdasarkan Tabel 2, diketahui bahwa sebagian besar responden memiliki status gizi normal $(61,2 \%)$. Persentase kejadian overweight dan obesitas dalam penelitian ini adalah $16,3 \%$ dan 22,4\%. Apabila dibandingkan dengan data Riskesdas pada penduduk dewasa di Indonesia tahun 2018, angka tersebut lebih tinggi, dimana persentase kejadian overweight dan obesitas di Indonesia sebesar $13,6 \%$ dan $21,8 \%^{3}$.

Berdasarkan tabel 3, mayoritas asupan energi responden tergolong baik (47\%) dan hanya sejumlah kecil responden asupan energinya lebih (10,2\%). Berdasarkan hasil wawancara menggunakan SQ-FFQ, banyak responden mengaku mengurangi bahan makanan sumber karbohidrat seperti nasi dan gula dengan alasan mencegah penyakit diabetes mellitus serta mengurangi konsumsi protein hewani seperti daging sapi dan daging kambing dengan alasan mencegah tingginya kadar kolesterol tubuh. Alasan tersebut menurunkan total asupan energi sehingga banyak responden dalam penelitian ini yang asupan energinya tergolong kurang serta hanya sedikit responden yang asupan energinya berlebih. Hasil penelitian ini sepadan dengan hasil penelitian yang dilakukan pada PNS di Dirjen Perimbangan Keuangan, yang menyatakan bahwa sebagian responden memiliki asupan energi yang baik $(91,9 \%)^{13}$.

Berdasarkan uji statistik menggunakan uji korelasi Pearson menunjukkan adanya hubungan yang searah antara asupan energi dengan IMT $(p=0,001 ; r=$ 0,472 ). Hasil penelitian ini selaras dengan penelitian terdahulu yang menyatakan adanya hubungan antara asupan energi dengan obesitas pada PNS di Direktorat Jenderal Perimbangan Keuangan ${ }^{13}$. Semakin besar kalori yang dikonsumsi tanpa dikeluarkan, akan memicu kenaikan berat badan dan obesitas, jika terjadi dalam jangka waktu yang lama 7,14 .

Pengukuran stres kerja menggunakan metode wawancara dengan bantuan kuesioner OSI-R (Occupational Stress Inventory-Revised) yang terdiri dari 25 pertanyaan kemudian dilakukan skoring untuk setiap jawaban responden. Berdasarkan tabel 3, dapat diketahui bahwa mayoritas responden mengalami stres tingkat sedang $(69,4 \%)$.

Hasil tersebut berbeda dengan hasil penelitian yang dilakukan pada Karyawan Dinas Ketenagakerjaan dan Transmigrasi Kota Malang. Dalam penelitian tersebut, rata-rata responden mengalami stres kerja tingkat rendah, baik stres kerja lingkungan, stres organisasional dan stres kerja personal ${ }^{15}$. Perbedaan hasil tersebut kemungkinan dikarenakan dalam penelitian ini seluruh responden memiliki jabatan sebagai manajer, sehingga dari segi beban kerja, tanggung jawab, pola hubungan antar tenaga kerja serta tuntutan dari atasan lebih berat apabila dibandingkan dengan karyawan. 
Tabel 3. Distribusi Asupan Energi, Stres Kerja, Aktifitas Fisik dan Durasi Waktu Tidur

\begin{tabular}{|c|c|c|c|}
\hline Variabel & Klasifikasi & $\mathbf{N}$ & $\%$ \\
\hline \multirow[t]{3}{*}{ Asupan Energi (kkal) } & Kurang (<80\% AKE) & 21 & 42,8 \\
\hline & Baik (80-110\% AKE) & 23 & 47 \\
\hline & Lebih (>110\% AKE) & 5 & 10,2 \\
\hline \multirow[t]{3}{*}{ Stres Kerja } & Rendah $(25-58)$ & 0 & 0 \\
\hline & Sedang (59-92) & 35 & 69,4 \\
\hline & Tinggi $(93-125)$ & 14 & 30,6 \\
\hline \multirow[t]{3}{*}{ Aktifitas Fisik } & Ringan $(1,40-1,69)$ & 23 & 46,9 \\
\hline & Sedang $(1,70-1,99)$ & 23 & 46,9 \\
\hline & Berat $(2,00-2,40)$ & 3 & 6,2 \\
\hline \multirow[t]{2}{*}{ Durasi Waktu Tidur (jam/hari) } & Kurang (<7 jam/ hari) & 29 & 59,2 \\
\hline & Cukup ( $\geq 7$ jam/hari) & 20 & 40,8 \\
\hline
\end{tabular}

Tabel 4. Rata-rata dan hasil uji korelasi asupan energi, stres kerja, aktifitas fisik dan durasi waktu tidur dengan IMT

\begin{tabular}{lcccc}
\hline \multicolumn{1}{c}{ Variabel } & Rata-Rata & Standar Deviasi & $\boldsymbol{P ~ v a l u e ~}^{*}$ & R \\
\hline Asupan Energi (kkal) & 1861,8 & 441,1 & 0,001 & 0,472 \\
Stres Kerja & 88,5 & 9,9 & 0,054 & 0,277 \\
Aktifitas Fisik & 1,7 & 0,17 & 0,148 & $-0,210$ \\
Durasi Waktu Tidur (jam/hari) & 6,4 & 0,82 & 0,006 & $-0,391$ \\
\hline
\end{tabular}

Keterangan: ${ }^{*}$ Uji statistik menggunakan korelasi pearson

Hasil uji statistik menggunakan korelasi pearson menunjukkan tidak adanya hubungan antara stres kerja dengan IMT $(p=0,054)$. Hasil penelitian ini berbeda dengan penelitian terdahulu yang menyatakan adanya hubungan yang signifikan antara stres dengan $\mathrm{IMT}^{16}$. Perbedaan hasil penelitian ini disebabkan adanya perbedaan jenis variabel stres yang diteliti dan perbedaan responden. Dalam penelitian ini, variabel stres yang diteliti lebih berfokus pada variabel stres kerja, sehingga tidak dapat menggambarkan kondisi stres seseorang secara menyeluruh. Stres kerja merupakan ketegangan emosi yang berasal dari lingkungan pekerjaan yang meyebabkan seseorang merasa frustasi, marah atau gugup. Stres merupakan faktor tidak langsung yang memengaruhi IMT melalui perubahan asupan makanan ${ }^{17,18}$. Secara teori, stres dapat memengaruhi perubahan preferensi makanan seseorang untuk cenderung mengonsumsi makanan tinggi lemak dan mengandung gula atau biasa disebut comfort food ${ }^{19}$. Meskipun demikian, respon stres antara satu orang dengan orang lain berbeda-beda. Beberapa orang akan mengalami peningkatan nafsu makan ketika sedang stres sedangkan yang lainnya justru mengalami penurunan nafsu makan ${ }^{20}$.

Berdasarkan Tabel 3 diketahui bahwa mayoritas aktifitas fisik responden dalam penelitian ini tergolong ringan $(46,9 \%)$ dan sedang $(46,9 \%)$. Tingkat aktifitas responden yang cenderung ringan dan sedang dalam penelitian ini dipengaruhi oleh tipe pekerjaan yang sebagian besar dilakukan di dalam ruangan. Hasil recall aktifitas fisik pada saat hari kerja menunjukkan bahwa sebagian besar responden menghabiskan waktu \pm 8 jam/hari untuk bekerja, beberapa responden mengaku pulang lembur. Kondisi macet di beberapa jalanan Kota Surabaya pada saat jam berangkat kantor mengharuskan sebagian besar responden untuk berangkat lebih pagi sehingga banyak yang tidak sempat melakukan olahraga sebelum berangkat ke kantor.

Hasil uji statistik menggunakan uji korelasi pearson menunjukkan tidak adanya hubungan antara PAL (Physical Activity Level) dengan IMT $(p=0,148)$. Hasil penelitian ini sejalan dengan penelitian yang dilakukan pada PNS di Kantor Dinas Kesehatan Provinsi Jawa Timur, yang menyatakan tidak adanya hubungan antara aktifitas fisik dengan status gizi, dimana dalam penelitian tersebut sebagian besar responden cenderung melakukan aktifitas fisik yang ringan ${ }^{21}$. Meskipun hasil penelitian tidak sesuai dengan teori, mayoritas responden dalam penelitian ini melakukan aktifitas fisik yang cenderung ringan dan sedang. Hal inilah yang dapat menyebabkan tidak adanya hubungan antara aktifitas fisik dengan IMT secara statistik. Secara teori dapat dinyatakan bahwa aktifitas fisik yang kurang merupakan salah satu faktor yang dapat menyebabkan risiko obesitas ${ }^{12}$. Apabila asupan kalori berlebihan dan tidak diimbangi dengan aktifitas fisik yang seimbang akan memudahkan seseorang mengalami kegemukan ${ }^{22}$.

Tidur merupakan bentuk istirahat untuk melepaskan kelelahan mental dan jasmani ${ }^{23}$. Kebutuhan waktu tidur berbeda-beada antar kelompok usia. Kebutuhan waktu tidur untuk orang dewasa usia 40-60 tahun adalah selama 7 jam dalam sehari24. Dalam penelitian ini, mayoritas responden (59,2\%) memiliki jam tidur yang kurang. Persentase responden yang kurang waktu tidur dalam penelitian ini sepadan dengan penelitian terdahulu yang menyatakan bahwa sebagian besar waktu tidur tenaga kesehatan puskesmas kurang dari 7 jam/hari $(56,5 \%)^{25}$. Pada saat dilakukan recall aktifitas fisik, sebagian besar responden mengaku bangun tidur lebih awal yaitu pukul $03.00-04.00$ WIB untuk melakukan ibadah malam. Selain itu, jam pulang kerja responden yaitu pukul 16.00 WIB, bahkan beberapa responden harus pulang lembur, sehingga 
tidak memungkinkan bagi responden untuk tidur di siang hari pada hari kerja.

Hasil uji statistik menggunakan uji korelasi pearson menunjukkan adanya hubungan antara durasi waktu tidur dengan indeks massa tubuh (IMT) $(p=0,006$; $r=-0,391$ ). Durasi waktu tidur yang kurang akan menjadi pendukung kejadian obesitas melalui berbagai macam mekanisme perubahan hormon ${ }^{26}$. Waktu tidur yang kurang akan menurunkan kadar hormon leptin dan meningkatkan hormon ghrelin sehingga nafsu makan akan meningkat ${ }^{27,28}$. Selain itu, durasi tidur malam yang kurang akan meningkatkan hormon kortisol, sehingga mempengaruhi kadar insulin dalam darah serta meningkatnya penimbunan lemak ${ }^{29}$. Growth hormone juga akan menurun apabila seseorang kurang tidur. Penurunan growth hormone akan memicu penyerapan glukosa pada sel, merangsang glikogenesis dan lipogenesis yang dapat menyebabkan kegemukan jika tejadi secara terus menerus ${ }^{27}$.

\section{KESIMPULAN}

Terdapat hubungan antara asupan energi dan durasi waktu tidur dengan IMT. Semakin tinggi asupan energi dan semakin singkat durasi waktu tidur maka semakin tinggi IMT pada manajer madya. Manajer madya disarankan untuk memantau dan mengontrol berat badan, menyeimbangkan antara asupan energi dengan aktifitas fisik serta tidur cukup selama 7 jam/ hari.

\section{ACKNOWLEDGEMENT}

Penulis mengucapkan terima kasih kepada Dosen Pembimbing atas bimbingan dan saran yang diberikan sehingga penulisan artikel ini dapat terselesaikan, seluruh responden yang telah bersedia mengikuti penelitian ini serta teman-teman enumerator yang telah membantu dalam proses pengambilan data.

\section{REFERENSI}

1. Suryana, A.L., Olivia, Z.Profil, D. A. N. \& Pegawai, L. Asupan Makan dan Profil Lipid Pegawai Dengan Status Gizi Normal dan Obesitas. J. IIm. Inov. 1, 155-162 (2016).

2. Adriani, M., Wirjatmadi, B. Pengantar Gizi Masyarakat. (Kencana Prenada Media Grup, 2012).

3. Kementrian Kesehatan RI. Hasil utama riskesdas 2018. 61 (2018). doi:1 Desember 2013

4. Sari, Kencana; Amaliah, N. Hubungan Faktor Sosial Demografi Dan Kegemukan Pada Penduduk Dewasa Di Indonesia Tahun 2007 Dan 2010 (Analisis Data Riskesdas 2007 Dan 2010). J. Ekol. Kesehat. 13, 328-339 (2014).

5. BKN. Pedoman Penyusunan Pola Karier Pegawai Negeri Sipil. 1-24 (2011).

6. Abadini, D. \& Wuryaningsih, C. E. Determinan Aktivitas Fisik Orang Dewasa Pekerja Kantoran di Jakarta Tahun 2018. J. Promosi Kesehat. Indones. 14, 15-28 (2019).
7. Damanik, S.M., Aritonang, E, Y., Nasution, E. Hubungan Pola Konsumsi Pangan dengan Tingkat Kolesterol Darah Total pada Pegawai Negeri Sipil di Kanwil Direktorat Jendral Perbendaharaan Provinsi Sumatera Utara Kota Medan Tahun 2013. J. Gizi, Kesehat. Reproduksi dan Epidemiol. 1, 1-7 (2014).

8. Hizbullah, M., Utami, W. Studi Peran Ganda Guru Sebagai Pejabat Struktural Sekolah dan Pengaruhnya Terhadap Kepuasan Kerja: Orientasi Profesional dan Ketidakjelasan Peran Sebagai Variabel Moderating. in Simposium Nasional Akuntansi Xiv Aceh 2011 1-25 (2011). doi:10.1145/2831296.2831338

9. Wijono, S. Pengaruh Kepribadian Type A dan Peran Terhadap Stres Kerja Manajer Madya. Psikologi 8, 188-197 (2006).

10. Sarwendah, E. Hubungan Beban Kerja dengan Tingkat Stres Kerja pada Pekerja Sosial Sebagai caregiver di Panti Sosial Tresna Werdha Budi Mulia DKI Jakarta. (Universitas Islam Negeri Syarif Hidayatullah Jakarta, 2013).

11. WHO/FAO/UNU. Human Energy Requirement: WHO Technical Report Series, No. 724. 0, (WHO, 2001).

12. Widiantini, W., Tafal, Z. Artikel Penelitian 330 Alamat Korespondensi: Winne Widiantini, Pusat Data dan Informasi Sekjen. J. Kesehat. Masy. Nas. 8, 330-336 (2013).

13. Astheria, K. \& Djokosujono, K. Hubungan Antara Karakteristik Individu, Asupan Gizi , dan Faktor Lainnya dengan Obesitas pada Pegawai Negeri Sipil Pria di Direktorat Jenderal Perimbangan Keuangan Tahun 2013. (Universitas Indonesia, 2013).

14. Mutiara, E. \& Yanti, E. N. Hubungan Keseimbangan Asupan Gizi Dan Aktivitas Fisik Dengan Kondisi Fisik Anak SD di Kecamatan Kotanopan. J. Unimed 23-31 (2012).

15. Ayu, C. P. \& Mukzam, M. D. Pengaruh Stress Kerja Lingkungan, Organisasional, dan Personal Terhadap Kepuasan Kerja (Studi pada Karyawan Dinas Ketenagakerjaan dan Transmigrasi Kota Malang). J. Adm. Bisnis 34, 104-113 (2016).

16. Purwanti, M., Putri, E. A., Ilmiawan, M. I., Wilson \& Rozalina. Hubungan Tingkat Stres dengan Indeks Massa Tubuh Mahasiswa PSPD FK Untan. J. Vokasi Kesehat. 3, 1-10 (2017).

17. Sikalak, W., Widajanti, L., Aruben, R. FaktorFaktor Yang Berhubungan Dengan Kejadian Obesitas Pada Karyawati Perusahaan Di Bidang Telekomunikasi Jakarta Tahun 2017. J. Kesehat. Masy. 5, 193-201 (2017).

18. Masdar, H., Saputri, P. A., Rosdiana, D. \& Chandra, F. Depresi, ansietas, dan stres serta hubungannya dengan obesitas pada remaja. J. Gizi Klin. Indones. 12, 138-143 (2016).

19. Finch, L. E. \& Tomiyama, A. J. Comfort eating, psychological stress, and depressive symptoms in young adult women. Appetite 95, 239-244 (2015). 
20. Sugianti, E., Hardinsyah., Afriansyah, N. Faktor risiko obesitas sentral Elya Sugianti, dkk. Gizi Indones. 32, 105-116 (2009).

21. Dewi, A. C. N. \& Mahmudiono, T. Hubungan Pola Makan, Aktivitas Fisik, Sikap, dan Pengetahuan Tentang Obesitas dengan Status Gizi Pegawai Negeri Sipil di Kantor Dinas Kesehatan Provinsi Jawa Timur. J. Media Gizi Indones. 9, 42-48 (2013).

22. Weni, K. I. K. et al. Faktor-faktor yang mempengaruhi kejadian obesitas pada remaja. $J$. Gizi Klin. Indones. 11, 179-190 (2015).

23. Prio, P. Durasi tidur singkat dan obesitas. J. Major. 4, 5-9 (2015).

24. Kementrian Kesehatan RI. Kebutuhan Tidur Sesuai Usia. (2018).

25. Ramadhaniah, Julia, M. \& Huriyati, E. Jurnal Gizi Klinik Indonesia Durasi tidur, asupan energi, dan aktivitas fisik dengan kejadian obesitas pada tenaga kesehatan puskesmas. J. Gizi Klin.
Indones. 11, 85-96 (2014).

26. Rusmini, N. . Durasi tidur dan obesitas pada dewasa awal usia 26 - 35 tahun di wilayah sidotopo wetan surabaya. Adi Husana Noursing J. 2, 81-84 (2016).

27. Endayati, D., Sudiarti, T. Perbedaan Durasi Tidur Malam Pada Orang Dewasa Obesitas dan Non Obesitas: Meta-Analisis STudi Cross Sectional 2005-2012. Penelit. Gizi dan Makanan 35, 119135 (1971).

28. Septiana, P. \& Irwanto, I. Hubungan Durasi Tidur dengan Kejadian Obesitas pada Anak Usia 3-8 Tahun. Glob. Med. Heal. Commun. 6, 63-67 (2018).

29. Bennedict, C., Hallsmichd, M., Lassen, A., Mahnke, C., Schultes, B., Schiot, H., B., Born, J., Lange, T. Acute sleep deprivation reduces energy expenditure in healthy men. Am. J. Clin. Nutr. Vol. 93, Issue 6, 1 June 2011, Pages 1229-1236 93, 1229-1236 (2011). 